\title{
Validasi Alat Penelitian Hidung Elektronik dengan Senyawa Alkohol Standar
}

\author{
Widyastuti $^{1}$ \\ 1Pranata Laboratorium Pendidikan, Departemen Fisika, Fakultas Matematika dan IImu \\ Pengetahuan Alam, Universitas Gadjah Mada
}

Submisi :: 24 Oktober 2020; Penerimaan: 20 November 2020

\begin{abstract}
ABSTRAK
Laboratorium Fisika Material saat ini tengah mengembangkan alat penelitian untuk mendeteksi sampel-sampel yang mengemisikan senyawa mudah menguap. "Hidung Elektronik". Alat ini merupakan sebuah alat sensor yang mempunyai kemampuan untuk mendeteksi zat-zat tertentu, mulai dari kandungan bahan berbahaya pada makanan seperti borax dan formalin, hingga mendeteksi sejumlah penyakit, menganalisa urine dan kebutuhan lainnya. Sehubungan dengan banyaknya pesanan alat Hidung Elektronik atau E-nose tersebut, maka kami memandang perlu adanya validasi terhadap alat yang akan diproduksi berikutnya, supaya hasilnya sama tepat dan cermat. Validasi yang kami lakukan menggunakan senyawa: aseton, etanol, metanol dan toluen. E-nose yang dikombinasikan dengan metode kemometrik memiliki hasil prediksi konsentrasi yang presisi dan memiliki repetabilitas yang baik. Selain itu, hasil penelitian ini menunjukkan bahwa reproduktibilitas sampel etanol, metanol, aseton, dan toluen berpengaruh besar terhadap pola respons masing-masing E-nose.
\end{abstract}

Kunci: Hidung Elektronik, Validasi Alat Ukur, Senyawa Volatil

\begin{abstract}
Currently the material physics laboratory developed a research instrument to detect samples emitting volatile compounds. The instrument called "Hidung Elektronik" or electronic nose. It consists of a sensor that has the ability to detect certain substances, from the dangerous substances in food (such as borax and formalin) to the early detection of diseases by analyzing urine, and other analysis. Due to the large number of orders for the electronic nose or e-nose device, we considered the need to perform validation in the production of the next device, in order to get the precision and accurate result. In this validation procedure, we used several compounds such as acetone, ethanol, methanol, and toluene. The result showed that the e-nose combined with the chemometric methods had precise result in concentration prediction and good repeatability. Furthermore, the result of this research indicated that the reproducibility of ethanol, methanol, aceton, dan toluene with standard compounds has a major effect on the the response pattern of e-nose.
\end{abstract}

Keywords: Electronic Nose, Instrument Validation, Volatile Compounds

\section{PENDAHULUAN}

Selama satu dasawarsa terakhir,
salah satu kelompok penelitian
instumentasi $\quad$ telah $r$ berhasil
mengembangkan alat penelitian yang
dikenal dengan "hidung elektronik", atau

disebut juga dengan electronic nose (enose). Untuk selanjutnya hidung elektronik akan disebut dengan e-nose. Alat penelitian berupa e-nose ini telah dikembangkan dengan berbagai tipe, 
dengan menggunakan 7 sampai dengan 16 sensor gas jenis oksida logam yang memiliki selektivitas global. E-nose ini telah dipakai untuk pengujian halal pada sampel-sampel makanan. Selain itu, enose yang tipe terbaru banyak diterapkan untuk penelitian yang terkait dengan otentikasi produk. E-nose ini sudah banyak digunakan untuk penelitian. Namun, alat ini belum dianggap sebagai alat standar. Oleh karena itu, apabila alat ini digunakan untuk aplikasi tertentu maka masih harus dilakukan validasi.

Mengacu pada definisi validasi dan verifikasi dalam Faridah, dkk (2018) tentang manajemen laboratorium, di dalam verifikasi metode, kinerja yang harus diuji adalah selektivitas, seperti uji akurasi (ketepatan) dan presisi (kecermatan). Dua hal ini merupakan hal yang paling minimal harus dilakukan dalam verifikasi sebuah metode. Suatu metode yang presisi (cermat) belum menjadi jaminan bahwa metode tersebut dikatakan tepat (akurat). Begitu juga sebaliknya, suatu metode yang tepat (akurat) belum tentu presisi.

Sementara itu, prosedur validasi harus diterapkan untuk metode tidak baku, metode yang dikembangkan sendiri oleh laboratorium, atau metode baku yang dimodifikasi. Validasi dilakukan untuk memastikan bahwa metode pengujian dengan alat, seperti $e$ nose tersebut, sesuai untuk penggunaan yang dimaksudkan, dan mampu menghasilkan data yang valid. Dalam melakukan validasi metode, parameter yang harus diuji meliputi: presisi, akurasi, batas deteksi atau limit of detection (LoD), batas kuantitasi atau limit of quantification (LoQ), selektivitas, linieritas, ripitabilitas, reproduksibilitas, ketahanan (robustness), sensivitas silang (cross-sensitivity), dan lain sebagainya.

Dalam pengertian yang lain, validasi metode uji perlu ditentukan untuk mengetahui kualitas dan kuantitas hasil uji dalam kaitannya akurasi pengukuran. Surapranata (2004) mengemukakan bahwa validitas adalah suatu tingkatan yang menyatakan bahwa suatu alat ukur telah sesuai dengan apa yang diukur yang dikaitkan dengan penelitian empiris. Para pengembang tes memiliki tanggung jawab dalam memuat tes yang benar-benar valid dan reliabel. Oleh karena itu validitas dapat digunakan dalam memeriksa secara langsung seberapa jauh suatu alat telah berfungsi dan hasilnya adalah akurat dan presisi. Berdasarkan uraian di atas, muncul gagasan untuk melakukan validasi metode uji dengan e-nose dengan mengacu pada standar SNI ISO/IEC 17025 dalam Faridah, dkk (2018).

\section{METODOLOGI PENELITIAN}

E-nose (Gambar 1) yang dikembangkan dilengkapi dengan larik sensor gas dan sensor SHT31 sebagai sensor suhu dan kelembaban ruangan sensor (Gambar 2). Selain itu, e-nose dilengkapi dengan datalogger yang diinstal di komputer. Datalogger ini digunakan untuk menyimpan data larik sensor yang dikirim oleh microcontroller ke komputer melalui koneksi serial. Lima buah alat penelitian e-nose hasil pengembangan di Lab Fisika Material (Fismatel) dengan tipe yang sama dari segi jumlah dan jenis sensor yang digunakan (Tabel 1). Hal ini bertujuan untuk melihat reproduksi dan repetabilitas alat penelitian. Selain itu, microsyringe $1 \mu \mathrm{L}$ digunakan untuk memasukkan larutan sampel ke dalam kantong sampel tertutup (Gambar 3). 


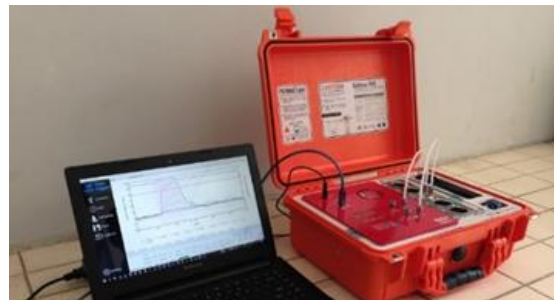

a

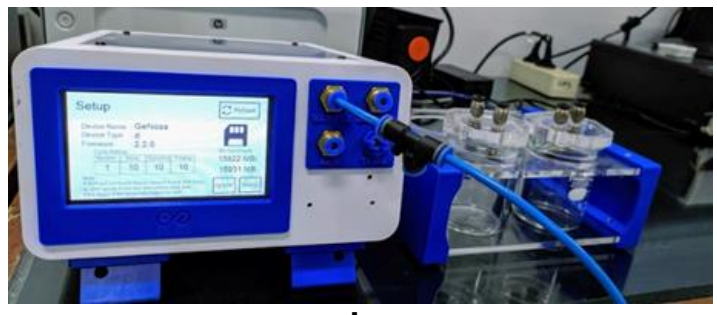

b

Gambar 1. E-nose untuk aplikasi deteksi halal (a) dan E-nose untuk aplikasi otentikasi produk (b)

Tabel 1. Perangkat e-nose

\begin{tabular}{cccc}
\hline No. & E-nose & Jumlah sensor gas & Kode \\
\hline 1 & GeNose Merah 1 & 10 & $\mathrm{M} 1$ \\
2 & GeNose Merah 2 & 10 & $\mathrm{M} 2$ \\
3 & GeNose Biru & 10 & $\mathrm{~B}$ \\
4 & GeNose Cokelat & 10 & $\mathrm{C}$ \\
5 & GeNose Hijau & 10 & $\mathrm{H}$ \\
\hline
\end{tabular}

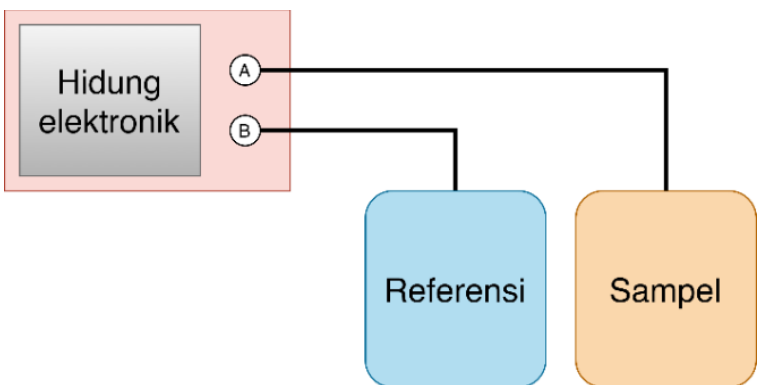

Gambar 2. Skema pengujian e-nose

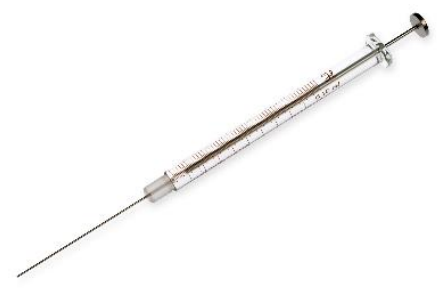

a

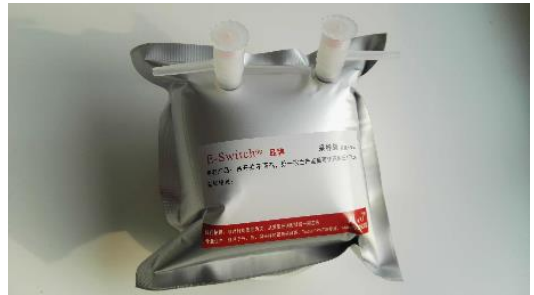

b

Gambar 3 Alat microsyringe (a) dan kantong sampel (b)

Senyawa standar yang akan digunakan mencakup kelompok alkohol, yaitu etanol dan metanol, serta senyawa bukan alkohol, yaitu aseton dan toluen. Tabel 2 menunjukkan bahan-bahan yang digunakan, meliputi jenis senyawa, jumlah sampel, dan variasi konsentrasi. Variasi konsentrasi senyawa di dalam kantong sampel dilakukan dengan cara mengkonversi perbandingan larutan yang dimasukkan ke dalam kantong sampel dengan volume penuh udara referensi. Volume analit $\left(V_{A}\right.$ dalam satuan $\mu \mathrm{L}$ ) yang dibutuhkan untuk variasi konsentrasi $C$ (dalam ppm) dapat dicari dengan pendekatan dalam Persamaan (1), dimana $M W$ adalah berat molekul $(\mathrm{g} / \mathrm{mol}), V_{s}$ adalah volume udara dalam kantong sampel (L), $\rho$ adalah kerapatan gas $(\mathrm{g} / \mathrm{mL})$, dan $T$ adalah suhu dalam kantong $(\mathrm{K})$. 
Tabel 2. Senyawa standar yang digunakan untuk validasi

\begin{tabular}{ccccccc}
\hline No. & Senyawa & Formula & $\begin{array}{c}\text { Titik didih } \\
\left({ }^{\circ} \mathrm{C}\right)\end{array}$ & $\begin{array}{c}\text { Kerapatan gas } \\
\left(\mathrm{kg} / \mathrm{m}^{3}\right)\end{array}$ & $\begin{array}{c}\text { Berat } \\
\text { molekul } \\
(\mathrm{g} / \mathrm{mol})\end{array}$ & $\begin{array}{c}\text { Variasi konsentrasi } \\
(\mathrm{ppm})^{*}\end{array}$ \\
\hline 1 & Etanol & $\mathrm{C}_{2} \mathrm{H}_{5} \mathrm{OH}$ & 78,37 & 789 & 46,7 & 10,20, \\
2 & Metanol & $\mathrm{CH}_{3} \mathrm{OH}$ & 64,70 & 792 & 32,04 & 40,60 \\
3 & Aseton & $\mathrm{C}_{3} \mathrm{H}_{6} \mathrm{O}$ & 56,00 & 784 & 58,08 & $80,100,120$ \\
4 & Toluen & $\mathrm{C}_{7} \mathrm{H}_{8}$ & 110,60 & 867 & 92,14 & \\
\hline
\end{tabular}

*untuk masing-masing alat penelitian

Penelitian ini dilakukan beberapa tahapan,yaitu:

a. Pengukuran respon larik sensor terhadap variasi suhu dan kelembaban.

b. Penentuan faktor koreksi suhu dan kelembaban.

c. Pengukuran respon larik sensor terhadap variasi konsentrasi setiap senyawa standar.

d. Penentuan akurasi dan presisi menggunakan analisis

kemometrik principal component analysis (PCA) dan linear discriminant analysis (LDA).

e. Penentuan batas deteksi dan korelasi linear dengan metode regresi partial least square (PLS) dan support vector machine regression (SVR).

\section{Pengujian sinyal sensor terhadap paparan analit}

Prosedur pengujian sinyal sensor terhadap paparan analit dapat dilihat pada Gambar 4. Persiapan alat dilakukan di awal waktu, yaitu dengan cara menghidupkan e-nose selama 30 menit untuk melakukan pemanasan larik sensor gas. Konfigurasi alat yang digunakan adalah 10 detik fase delay, 40 detik fase sampling, dan 180 detik fase purging. Dalam fase delay dan fase purging, udara yang masuk ruang sensor adalah udara dari referensi, sedangkan pada saat fase sampling, udara dari kantong sampel akan dihisap ke dalam ruang sensor. Fase purging digunakan untuk membersihkan ruang sensor dari gas atau analit sebelumnya.

\section{Persiapan sampel}

Persiapan sampel dilakukan dengan cara memasukkan udara referensi ke dalam kantong sampel sampai penuh, kemudian memasukkan analit (sampel larutan standar) ke dalam kantong sampel menggunakan microsyringe. Volume analit yang dimasukkan ke dalam kantong sampel sebanyak hasil perhitungan sesuai Persamaan (1). Prosedur pengambilan data dengan cara menghubungkan perangkat GeNose dengan komputer yang sudah terinstal GeNose datalogger melalui koneksi serial (kabel USB). Selain itu, kantong sampel (Gambar 3) yang telah disiapkan dihubungkan dengan perangkat GeNose (Gambar 2) dengan menggunakan selang teflon 4 $\mathrm{mm}$ ke konektor SENSOR di perangkat GeNose (A). Dalam penelitian ini, udara luar digunakan sebagai udara referensi (B).

\section{Uji performa e-nose terhadap proses sampling}

Hasil dari pembacaan e-nose ini merupakan respon yang diukur dari 10 larik sensor gas dan sensor suhu/kelembaban. Adapun tambahan sensor suhu/kelembaban adalah untuk mengetahui kondisi kelembaban dan suhu di dalam ruang sampling. Hasil respon yang keluar dari pengukuran sensor pada e-nose berupa nilai tegangan terukur $(\mathrm{mV})$ terhadap waktu sampling. Nilai tegangan yang terukur 
sebanding dengan konsentrasi gas yang diserap oleh sensor. Hasil pengukuran dari setiap proses sampling disimpan dalam bentuk *.csv ke dalam computer dengan menggunakan software akuisisi data yang telah dikembangkan, yaitu GeNose Data Logger yang tampilannya telah ditunjukkan pada Gambar 5.

\section{Prosedur analisis data GeNose}

Analisis data GeNose dilakukan dengan menggunakan pemrograman open source Python versi 3.8 yang dilengkapi dengan paket pandas, numpy, scikit-learn, dan matplotlib. Metode yang digunakan adalah Principal component analysis, PCA, digunakan untuk melihat distribusi data secara natural. PCA memiliki kemampuan untuk mereduksi jumlah dimensi data ke dalam variabel baru yang dinamakan principal component $(\mathrm{PC})$ menggunakan transformasi ortogonal. PC pertama memiliki nilai variabilitas terbesar terhadap variabel asli, sehingga yang memiliki peran terbesar dalam merepresentasikan variabel asli. Linear discriminantanalysis, LDA, digunakan untuk mereduksi dimensi data seperti PCA tetapi terhadap kategori kelas yang telah ditentukan. Selain dapat mereduksi dimensi data, LDA dapat digunakan untuk mengklasifikasi jenis sampel yang berbeda. Partial least square (PLS) dan support vectormachine regression (SVR) merupakan metode analisis data menggunakan algoritma terbimbing untuk permasalahan regresi. Kedua model regresi ini digunakan untuk memprediksi konsentrasi gas dari data GeNose.
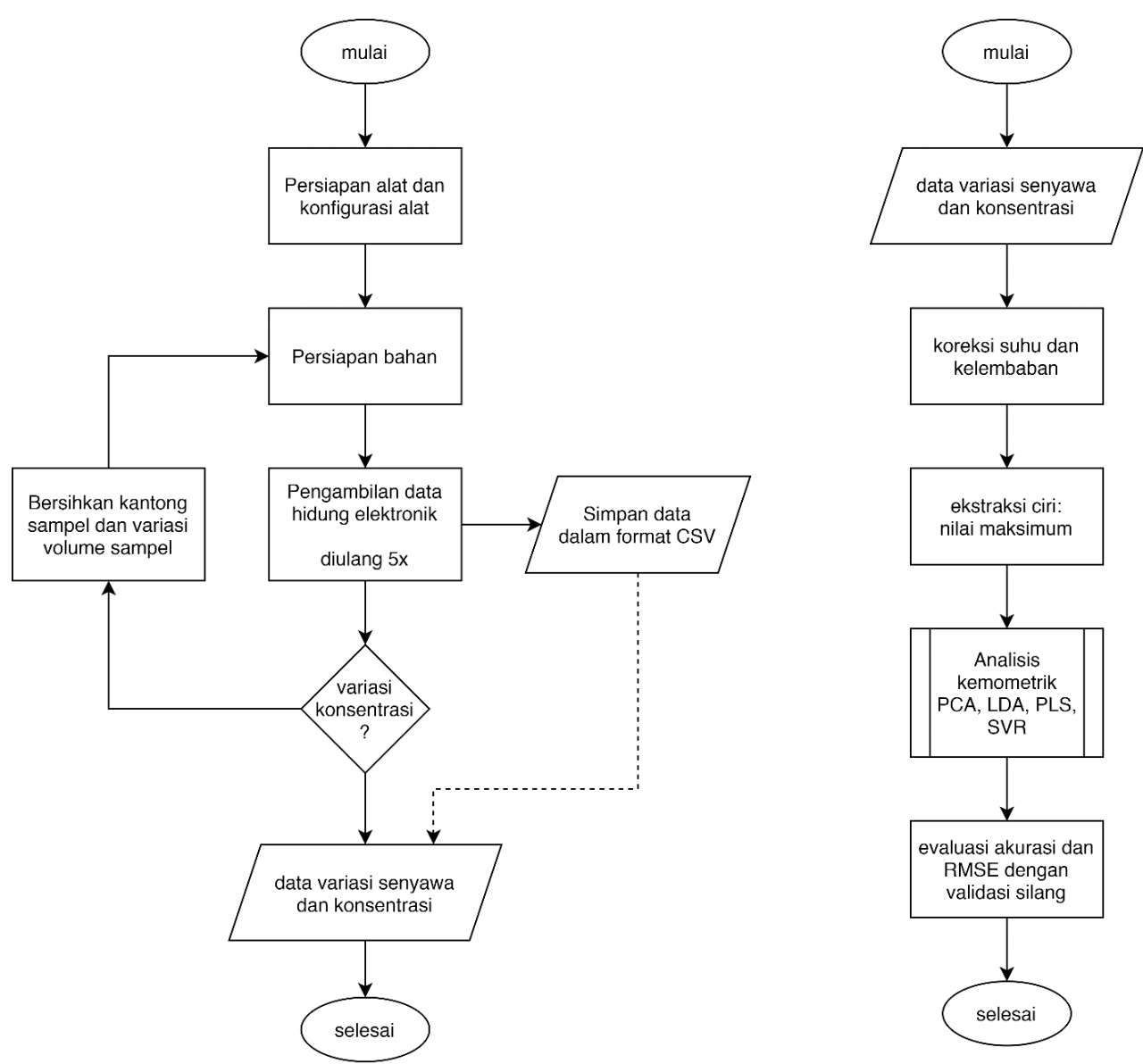

Gambar 4. Diagram alur pengujian respons sinyal sensor terhadap paparan analit. 


\section{HASIL DAN PEMBAHASAN}

Nilai suhu ruang sensor selama pengukuran tidak ada perubahan yang signifikan, sedangkan kelembaban ruang sensor berubah saat proses sampling (atau udara dari bag ke ruang sensor). Penurunan kelembaban ini disebabkan oleh perbedaan udara referensi dan udara kantong sampel. Udara kantong sampel menggunakan udara dari kompresor yang memiliki filter kelembaban, sehingga diperoleh udara kering. Oleh karena itu, kelembaban ruang sensor berkurang secara signifikan saat udara dari kantong sampel masuk ke dalam ruang sensor.

Hasil pengujian satu perangkat $e$ nose terhadap variasi empat jenis gas dan konsentrasi menghasilkan 700 data ( 5 e-nose $\times 4$ variasi jenis gas $\times 7$ variasi konsentrasi $\times 5$ perulangan). Gambar 5 menggambarkan satu data, sehingga 700 data memiliki ukuran yang besar. Oleh karena itu, metode ekstraksi ciri diterapkan untuk masing-masing data. Metode ekstraksi ciri digunakan untuk memperoleh nilai yang mewakili seluruh data. Dalam penelitian ini, metode ekstraksi ciri nilai maksimum diterapkan. Metode ini telah banyak digunakan dalam penelitian e-nose, seperti mendeteksi kualitas biji kakao dengan $e$ nose (Hidayat et al., 2019) dan mendeteksi kualitas teh hitam dengan $e$ nose (Hidayat et al., 2019).

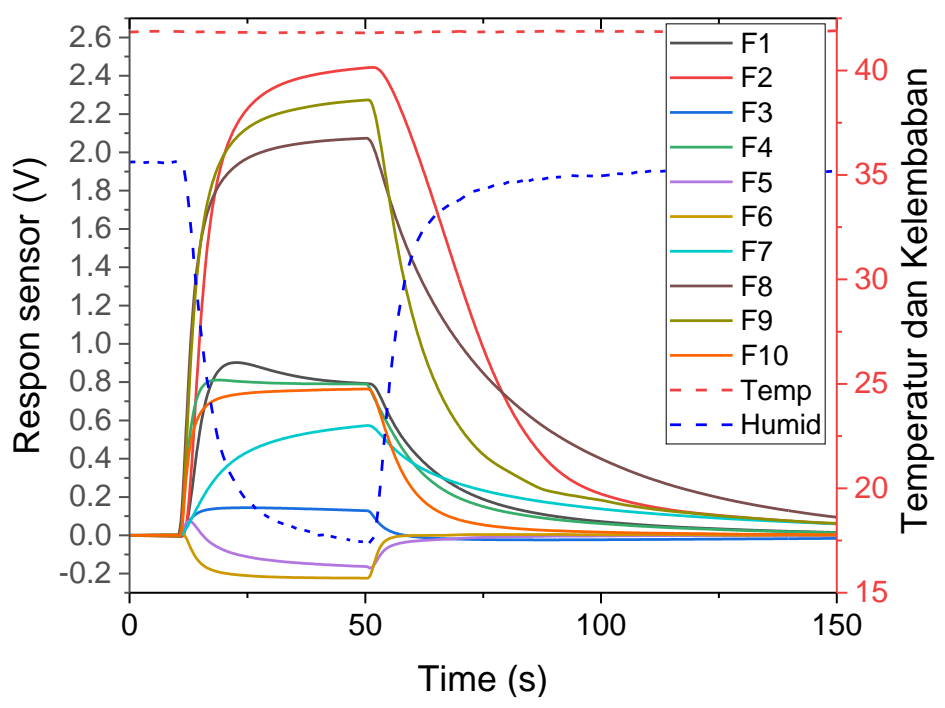

Gambar 5. Respon keluaran e-nose terhadap gas aseton 10 ppm

Gambar 6 menunjukkan respon Enose $\mathrm{H}$ terhadap variasi konsentrasi (ppm) untuk (a) aseton, (b) etanol, (c) metanol, dan (d) toluen jika konsentrasi 5 ppm sebagai titik nol. Konsentrasi gas semakin besar menyebabkan saturasi. Hasil tersebut menunjukkan untuk gas aseton dipilih konsentrasi maksimal 80 ppm, gas etanol 80 ppm, gas metanol 40 $\mathrm{ppm}$, dan gas toluen $60 \mathrm{ppm}$. Akan tetapi, hasil tersebut menunjukkan tidak konsisten hasil variasi konsentrasi dengan respons sensor. Hal ini kemungkinan besar karena reproduksibilitas dalam pembuatan gas standard yang tidak baik, disebabkan keadaan lingkungan tidak sesuai dengan persamaan konversi larutan ke gas, udara referensi yang tidak seragam, larutan yang disuntik tidak menguap secara sempurna, masih tersisa residu di 
dalam kantong sampel saat menyuntik cairan sampel.

Kemungkinan kesalahan dari alat kecil, karena nilai repeatabilitas tinggi di setiap perulangan kantong sampel yang sama, yang ditunjukkan dalam Gambar 10. Hal ini juga didukung dengan hasil Gambar (b) yang menunjukkan bahwa hasil dari 2 kali pembuatan sampel standard terdapat perbedaan pola antara pembuatan sampel pertama dan sampel kedua. Oleh karena itu, kalibrasi sulit antar e-nose tidak mudah dilakukan jika hasil pembuatan sampel tidak standard, hal ini dapat ditunjukkan dalam Gambar . Berdasarkan gambar tersebut, terdapat perbedaan pola yang signifikan untuk masing-masing e-nose, dengan sampel yang sama, tetapi berbeda kantong sampel.

Gambar 2 menunjukkan hasil analisis PCA untuk masing-masing enose terhadap gas aseton $80 \mathrm{ppm}$, etanol $80 \mathrm{ppm}$, metanol $40 \mathrm{ppm}$, dan toluen $60 \mathrm{ppm}$. Hasil ini mengilustrasikan penyederhanaan dimensi data dari 10 dimensi (10 sensor) ke 2 dimensi (PC1 dan PC2), sehingga variabilitas masingmasing data dapat dilihat secara visual. Hasil ini menunjukkan secara natural masing-masing e-nose memiliki respons yang berbeda terhadap jenis gas yang sama. Hal ini ditunjukkan dengan data satu tipe e-nose saling berdekatan, tetapi data antar e-nose saling berjauhan. Sedangkan pola yang diinginkan adalah semua data menjadi satu klaster yang besar untuk masing-masing jenis sampel, sehingga tidak terjadi pengelompokan masing-masing e-nose. Hal ini seperti yang dijelaskan di awal, disebabkan oleh reproduksibilitas pembuatan sampel gas yang tidak baik, sehingga tidak dapat dijadikan standard. Mengacu penelitian (Fonollosa et al., 2016) yang telah membuktikan bahwa dengan koreksi antar e-nose dapat dilakukan jika menggunakan sampel gas yang standard dan terukur.

Performa e-nose terhadap variasi konsentrasi gas memiliki performa yang tinggi, salah satu contohnya adalah Enose $\mathrm{H}$ dengan sampel gas aseton. Gambar (a) menunjukkan analisis PCA, masing-masing konsentrasi aseton terkluster dengan baik, jumlah PC1 dan PC2 mencapai $86,97 \%$ yang mewakili variabilitas data asli. Hasil ini divalidasi dengan analisis LDA yang ditunjukkan dalam Gambar (b), menunjukkan masing-masing konsentrasi dapat diprediksi dengan akurasi $100 \%$ menggunakan metode validasi silang leave-one-out. Gambar (c) menunjukkan plot regresi model PLS. Model PLS merupakan model linear, sehingga hasil ini membuktikan bahwa setelah konsentrasi $80 \mathrm{ppm}$, repons sensor cenderung saturasi (tidak linear). Oleh karena itu, plot regresi model non-linear SVR, Gambar (d), menghasilkan prediksi yang lebih baik.

\section{KESIMPULAN}

Berdasarkan hasil penelitian, dapat diambil kesimpulan berupa:

1. Pembuatan sampel standard sangat berpengaruh terhadap performa e-nose, sampel yang tidak standard menyebabkan $e$ nose satu dengan yang lain tidak memiliki pola yang sama. Selain itu, sampel yang tidak standard menyebabkan validasi atau kalibrasi antar e-nose tidak mudah dilakukan.

2. Perfoma repeatabilitas masingmasing e-nose dihasilkan nilai tinggi, yang dibuktikan dengan pola yang seragam untuk masingmasing perulangan pengambilan data kantong sampel yang sama.

3. Performa e-nose yang dikombinasikan dengan analisis kemometrik, dapat memprediksi 
konsentrasi gas dengan ketelitian yang tinggi.

\section{DAFTAR PUSTAKA}

Faridah, D. N., Erawan, D., Sutria, K., Hadi, A., Budiantari, F., 2018, Implementasi

SNI ISO/IEC/17025:2017, $\quad B S N$ : Jakarta.

Fonollosa, J., Fernández, L., GutiérrezGálvez, A., Huerta, R. \& Marco, S., 2016, Calibration transfer and drift counteraction in chemical sensor arrays using Direct Standardization, Sensors Actuators B Chem., 236, 10441053.

Hidayat, S., Rusman, A., Julian, T., Triyana, K., Veloso, A. \& Peres, A., 2019, Electronic Nose Coupled with Linear and Nonlinear Supervised Learning Methods for

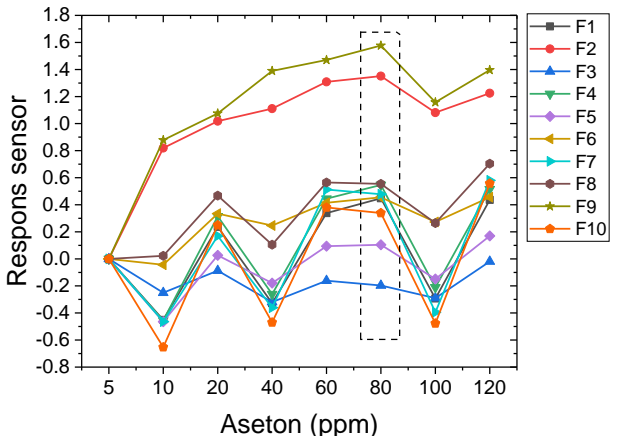

(a)

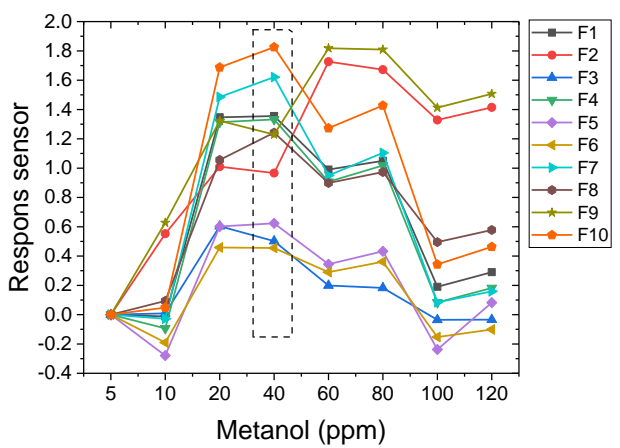

(c)
Rapid Discriminating Quality Grades of Superior Java Cocoa Beans, Int. J. Intell. Eng. Syst., 12, 6, 167-176.

Hidayat, S.N., Triyana, K., Fauzan, I. \& Julian, T., 2019, The Electronic Nose Coupled with Chemometric Tools for Discriminating the Quality of Black Tea Samples In Situ, Chemosensors, 7, 3, 29.

Rosa, Y., 2012, Perencanaan dan Penerapan Preventive Maintenance Peralatan Laboratorium, J. Tek. Mesin, 2, 2, 106-119.

Suntoro, A., 2013, Fenomena Akibat Lemahnya Program Perawatan Dalam Operasi Perangkat Listrik, PRIMA-Aplikasi dan Rekayasa dalam Bid. Iptek Nukl., 8, 1, 1-7.

Supranata, S., 2006, Analisis, Validitas, Reliabilitas, dan Interpretasi Hasil tes: Implementasi Kurikulum 2004, Remaja Rosdakarya: Samarinda.

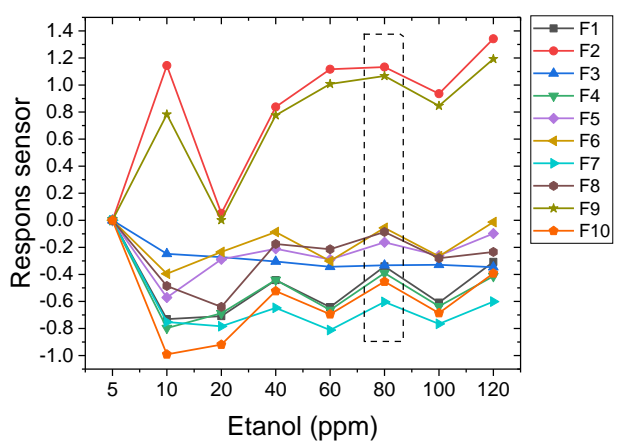

(b)

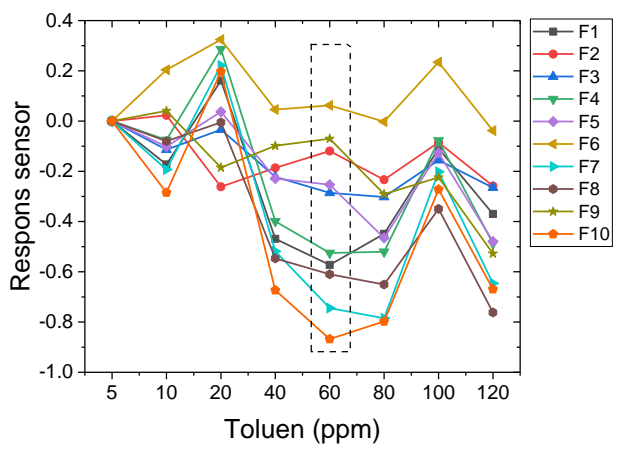

(d)

Gambar 6. Respon e-nose $\mathrm{H}$ terhadap variasi konsentrasi (ppm) untuk (a) aseton, (b) etanol, (c) metanol, dan (d) toluen jika konsentrasi 5 ppm sebagai titik nol. 
Widyastuti/ Vol 3 (1) 2020, 20-33

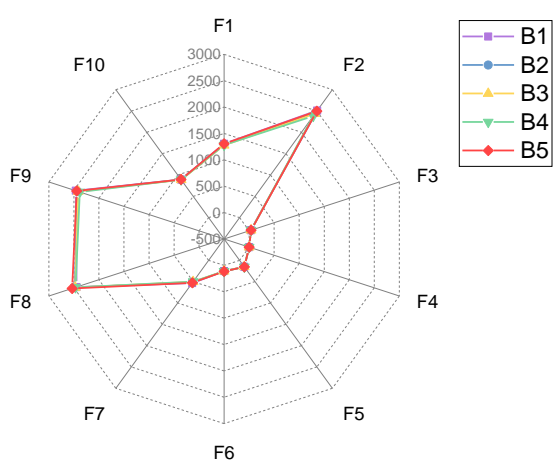

(a)

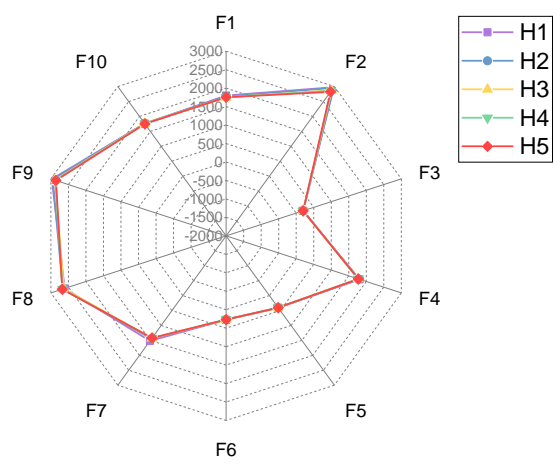

(c)

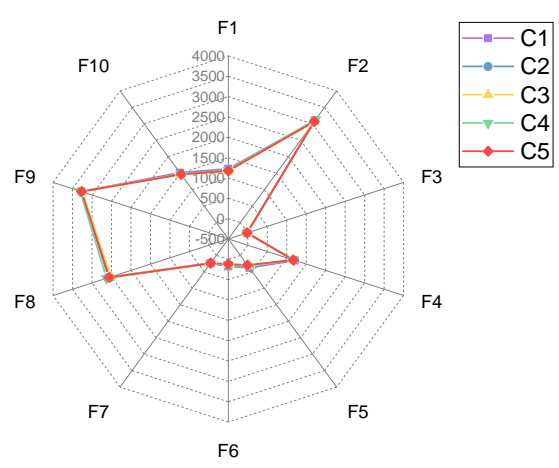

(b)

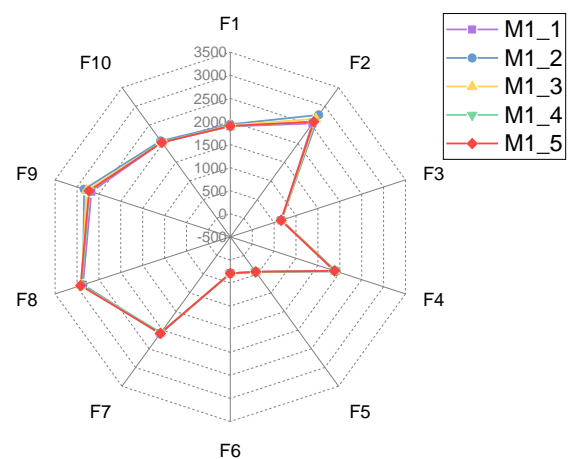

(d)

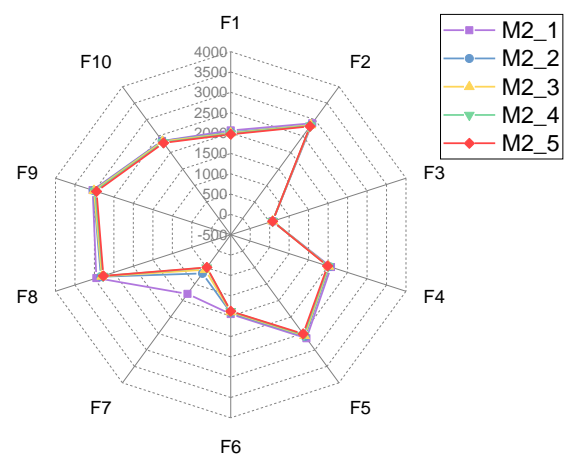

(e)

Gambar 7 (a) E-nose B gas aseton 80 ppm, (b) e-nose $C$ gas aseton 80 ppm, (c) e-nose $\mathrm{H}$ gas aseton 80 ppm, (d) e-nose M1 gas aseton 80 ppm, dan (e) e-nose M2 gas aseton $80 \mathrm{ppm}$. 
Widyastuti/ Vol 3 (1) 2020, 20-33

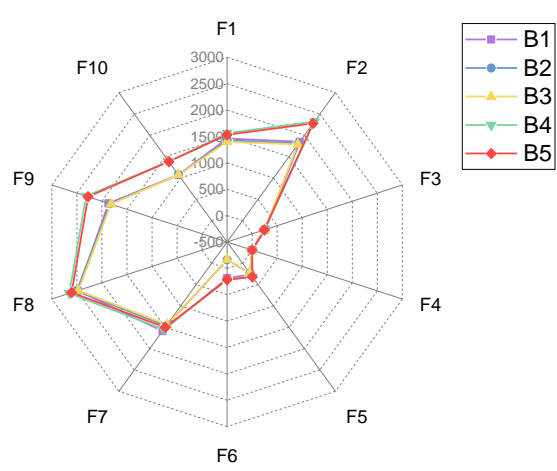

(a)

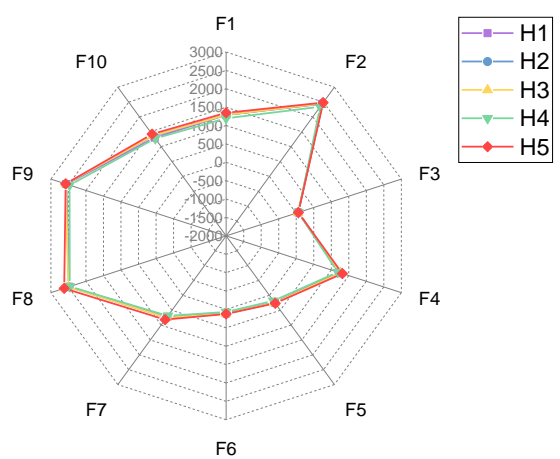

(c)

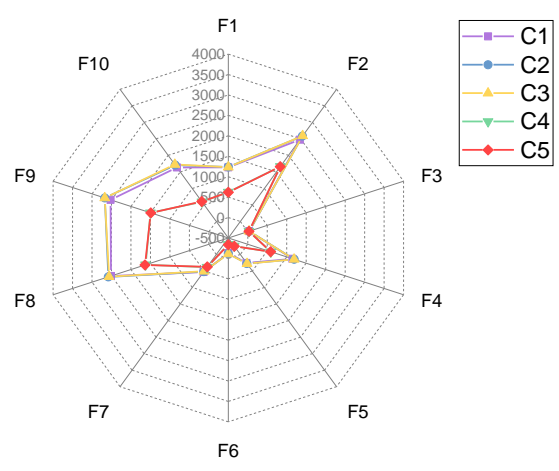

(b)

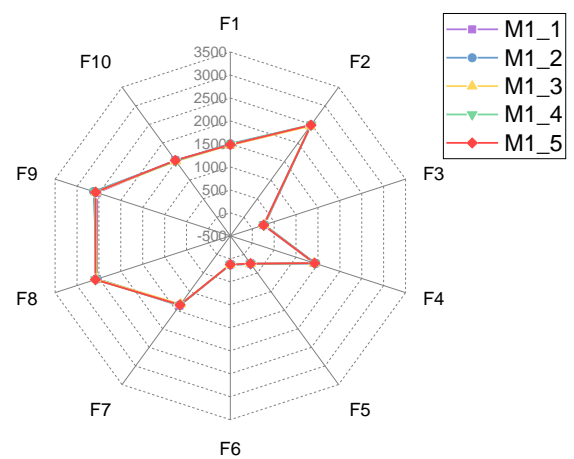

(d)

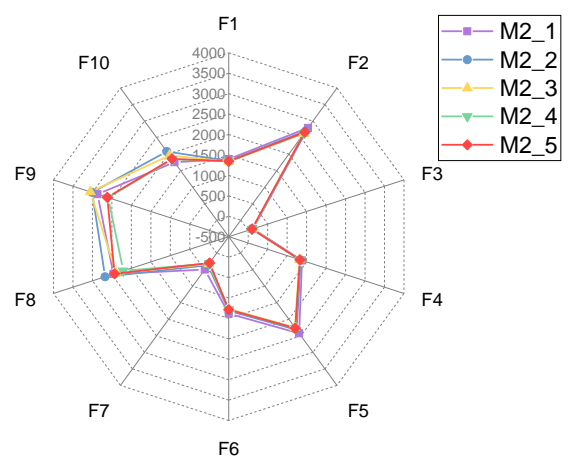

(e)

Gambar 8. (a) E-nose B gas etanol 80 ppm, (b) e-nose $C$ gas etanol 80 ppm, (c) e-nose $\mathrm{H}$ gas etanol 80 ppm, (d) e-nose M1 gas etanol 80 ppm, dan (e) e-nose M2 gas etanol 80 ppm. 


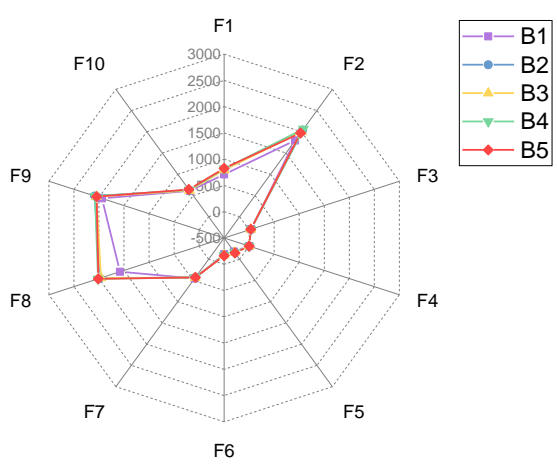

(a)

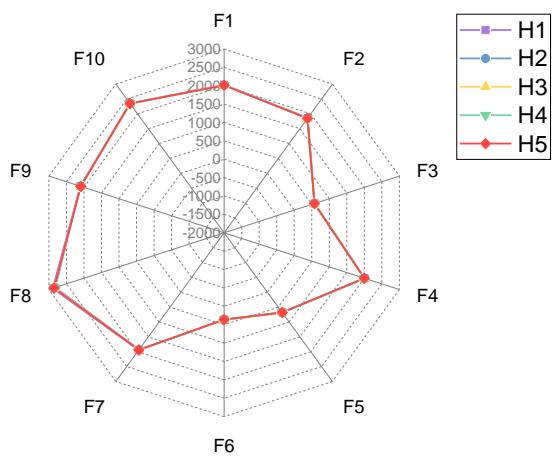

(c)

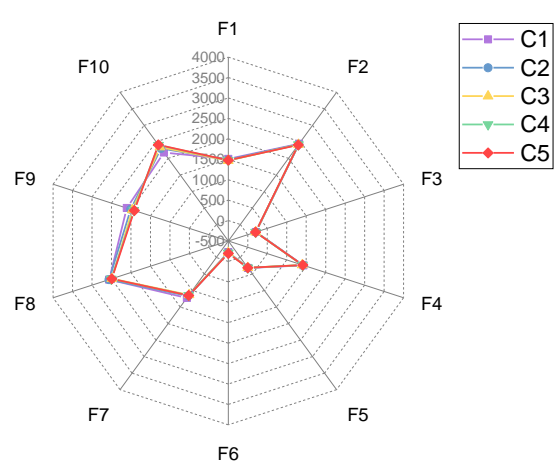

(b)

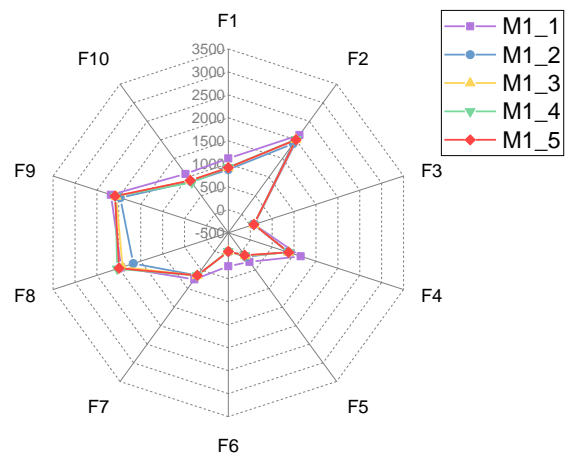

(d)

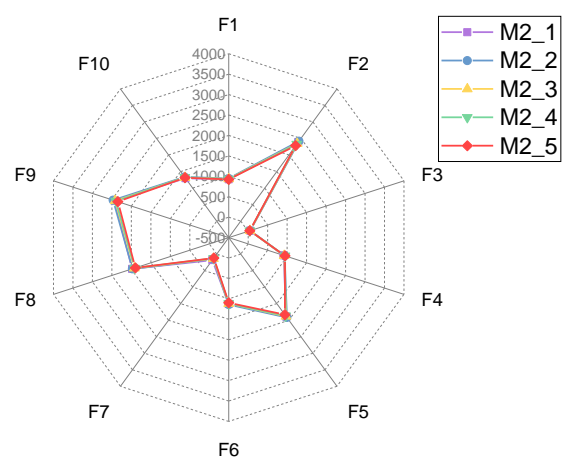

(e)

Gambar 9. (a) E-nose B gas methanol $40 \mathrm{ppm}$, (b) e-nose $\mathrm{C}$ gas metanol $40 \mathrm{ppm}$, (c) enose $\mathrm{H}$ gas metanol 40 ppm, (d) e-nose M1 gas metanol 40 ppm, dan (e) e-nose M2 gas metanol $40 \mathrm{ppm}$. 
Widyastuti/ Vol 3 (1) 2020, 20-33

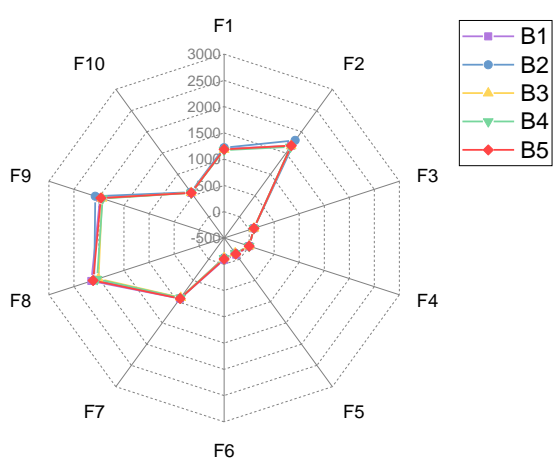

(a)

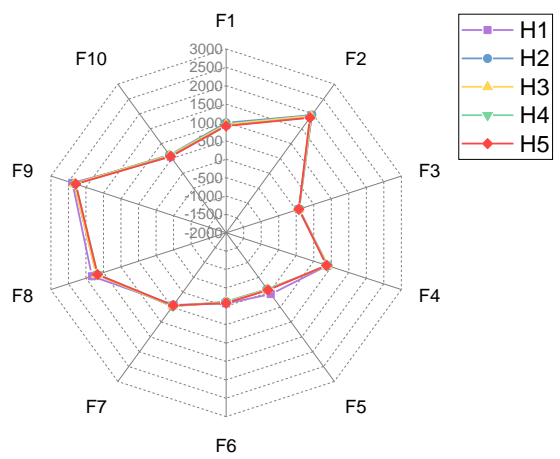

(c)

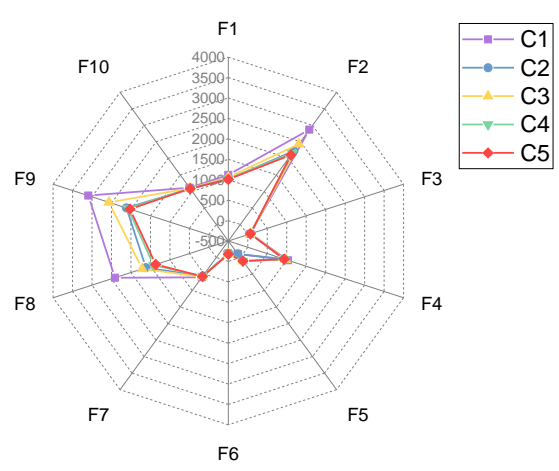

(b)

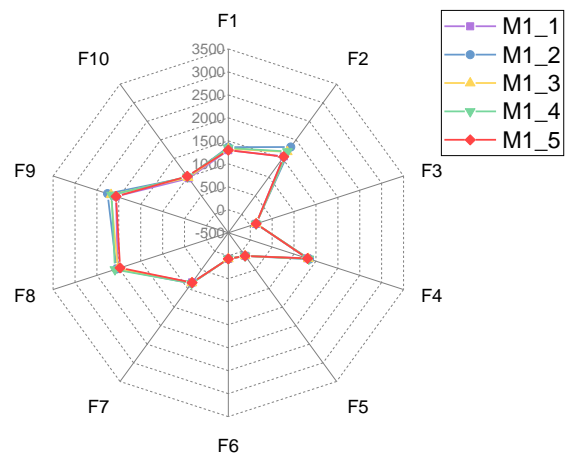

(d)

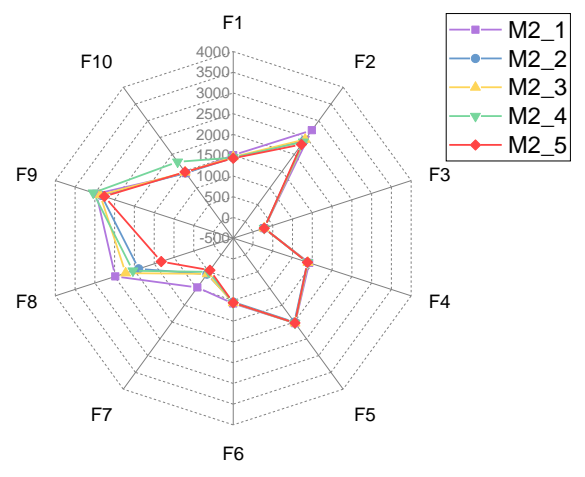

(e)

Gambar 10. (a) E-nose B gas toluen $60 \mathrm{ppm}$, (b) e-nose $C$ gas toluen $60 \mathrm{ppm}$, (c) e-nose $\mathrm{H}$ gas toluen $60 \mathrm{ppm}$, (d) e-nose M1 gas toluen $60 \mathrm{ppm}$, dan (e) e-nose M2 gas toluen 60 ppm. 


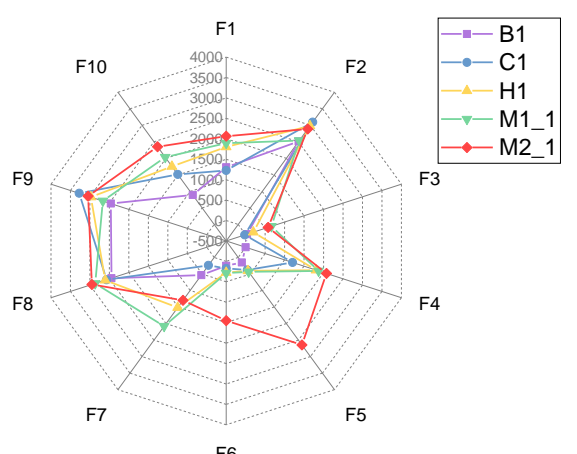

(a)

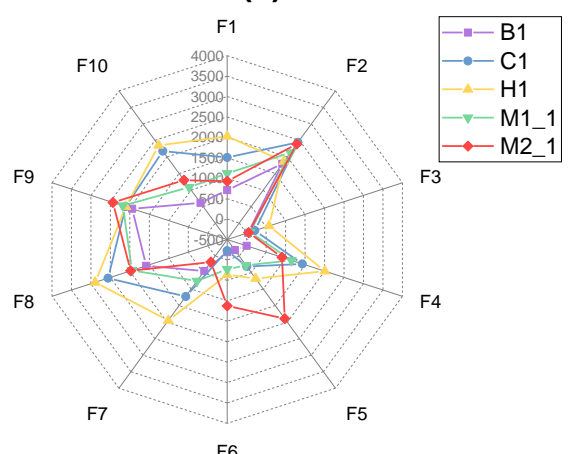

(c)

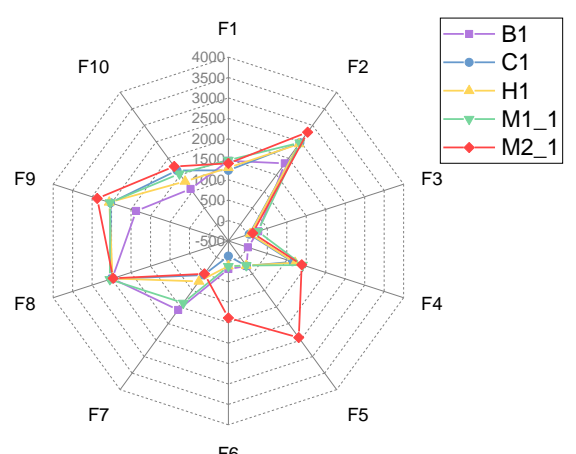

(b)

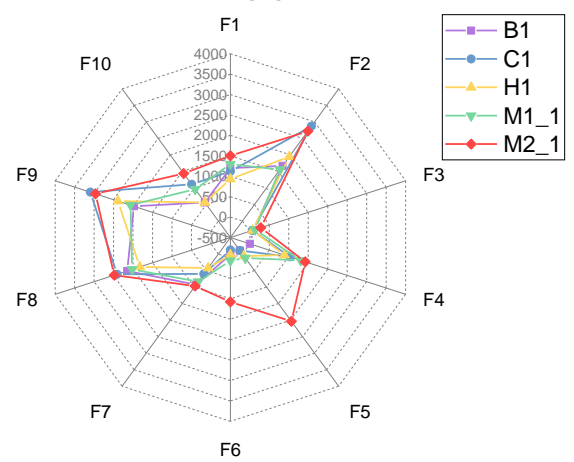

(d)

Gambar 11. Hasil perbandingan lima e-nose terhadap gas (a) aseton 80 ppm, (b) etanol 80 ppm, (c) metanol 40 ppm, dan (d) toluen 60 ppm.0

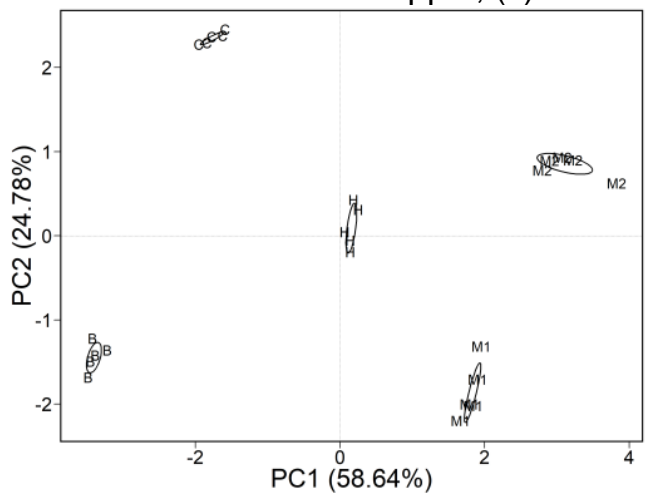

(a)

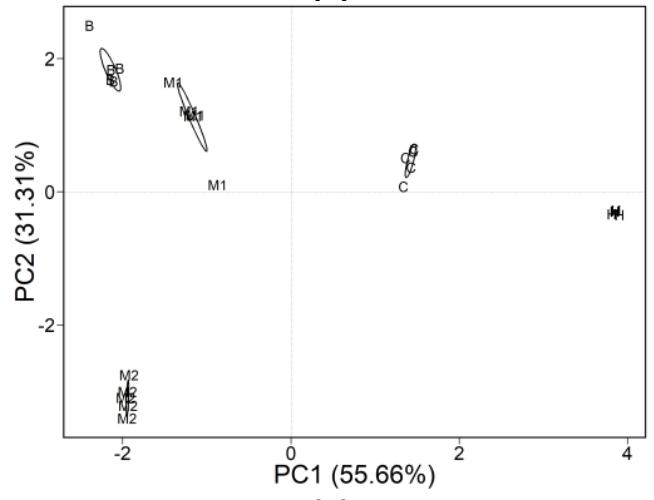

(c)

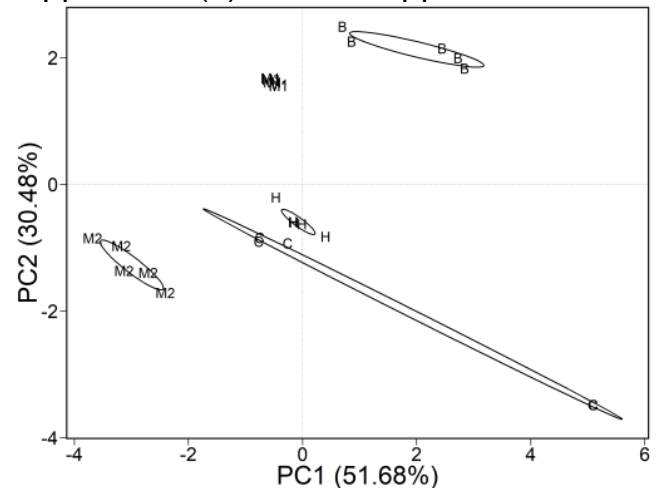

(b)

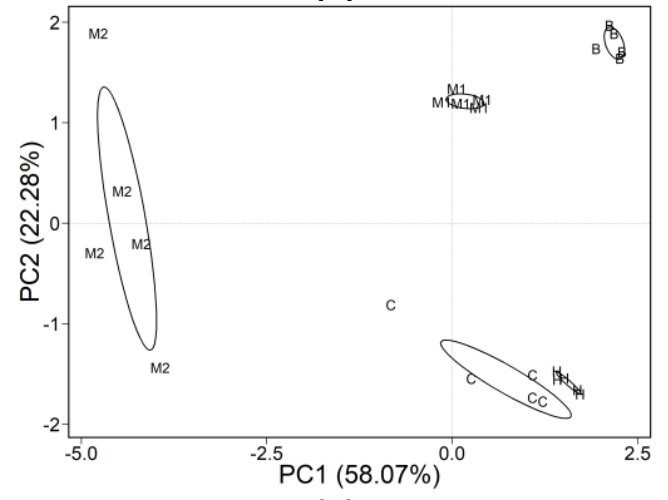

(d)

Gambar 2 Hasil analisis PCA dari 5 e-nose terhadap gas (a) aseton 80 ppm, (b) etanol 80 ppm, (c) metanol 40 ppm, dan (d) toluen 60 ppm. 


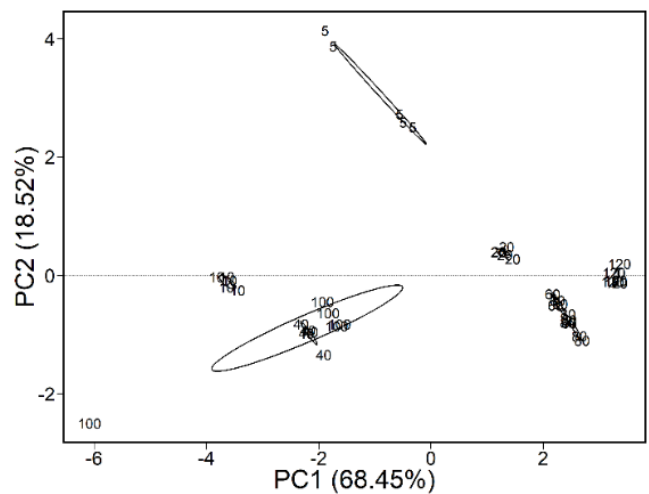

(a)

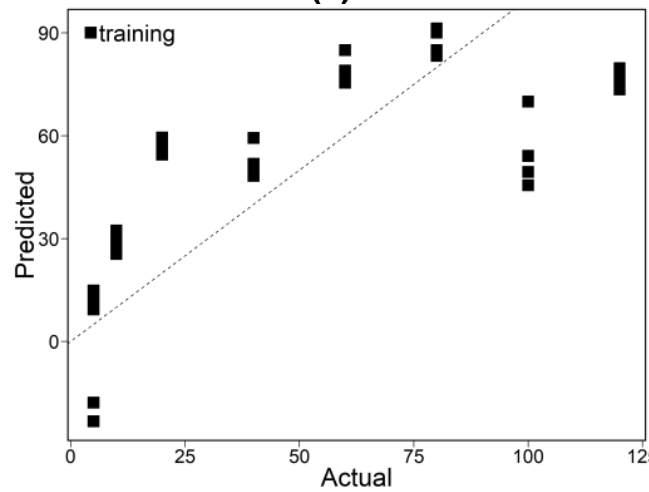

(c)

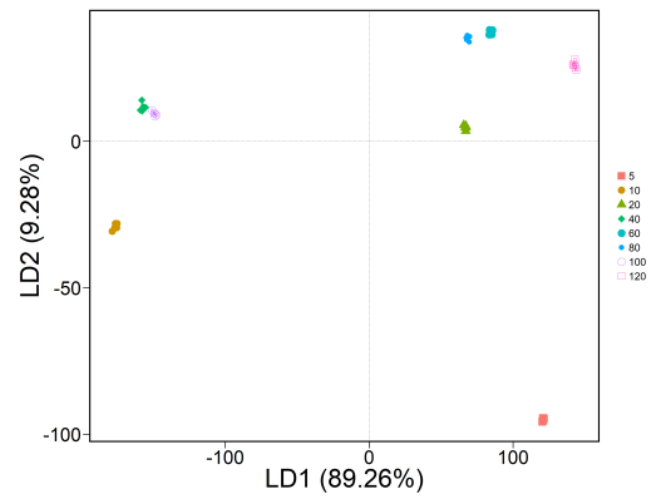

(b)

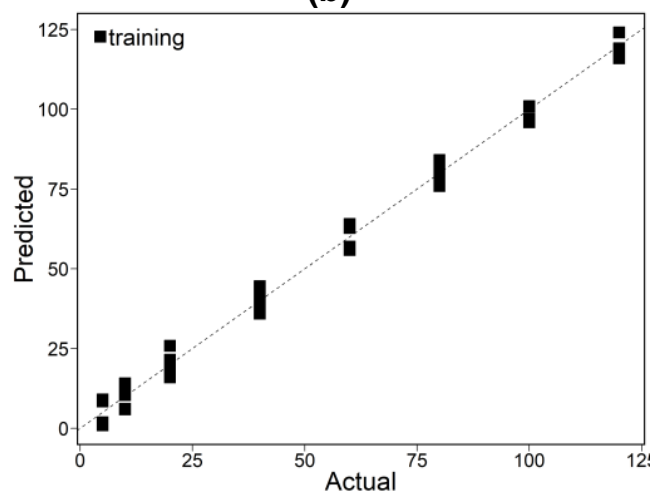

(d)

Gambar 12 Hasil analisis (a) PCA, (b) LDA, (c) PLS, dan (d) SVR e-nose H terhadap gas aseton dengan variasi konsentrasi 5, 10, 20, 40, 60, 80, 100, dan 120 ppm 